\title{
Дизайнерские принципы устранения потерь изображений в мозаичных фотоприемниках сверхвысокой размерности
}

\author{
А.И. Козлов ${ }^{1)}$, А.Р. Новоселов ${ }^{2)}$, В.Н. Овсюк ${ }^{1)}$ \\ ${ }^{1}$ Институт физики полупроводников им. А.В.Ржанова СО РАН, Новосибирск, 630090, \\ пр. Ак. Лаврентьева, 13 \\ ${ }^{2}$ Новосибирский филиал ИФП СО РАН "Конструкторско-технологический институт прикладной \\ микроэлектроники” (КТИПМ), \\ Новосибирск, 630090, пр-т Акад. Лаврентьева, 2/1 \\ тел: +7 (383) 333-1957, факс: +7 (383) 333-2771, эл. почта: kozlov@isp.nsc.ru
}

DOI 10.34077/RCSP2019-171

Разработаны и исследованы дизайнерские принципы создания мозаичных фотоприемников (МФП) изображений сверхвысокой размерности инфракрасного (ИК) и терагерцового (ТГц) спектральных диапазонов (рис.). МФП сверхвысокой размерности создают путем размещения на пластине-носителе (1) стык в стык кристаллов фотоприемных субмодулей (7) меньшего, приемлемого для изготовления формата [1-6]. Применение МФП ограничивается "слепыми зонами", обусловленными отсутствием фоточувствительных элементов (ФЧЭ) вдоль линий стыковки

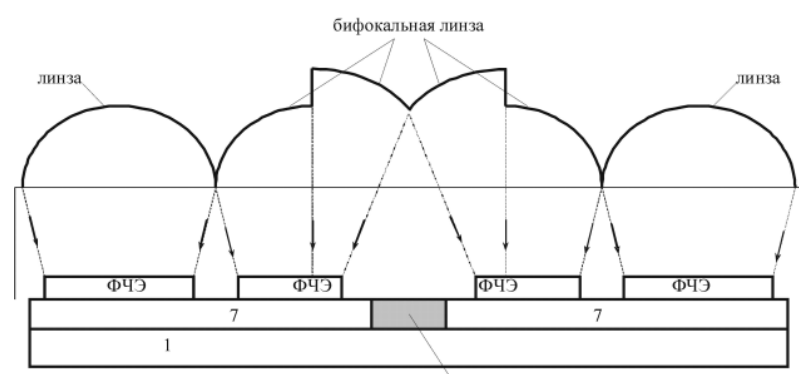

область стыковки субмодулей

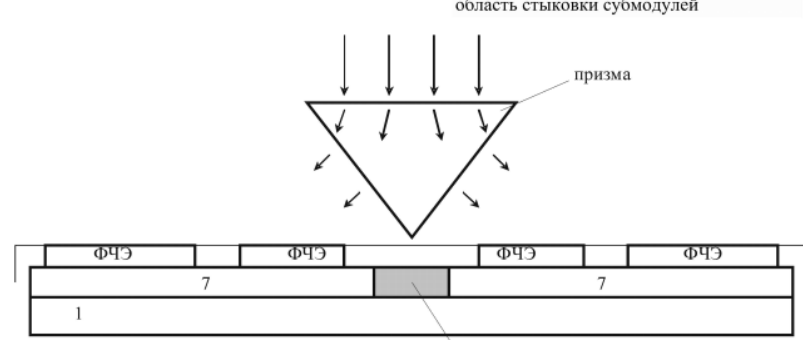

область стыковки субмодулей

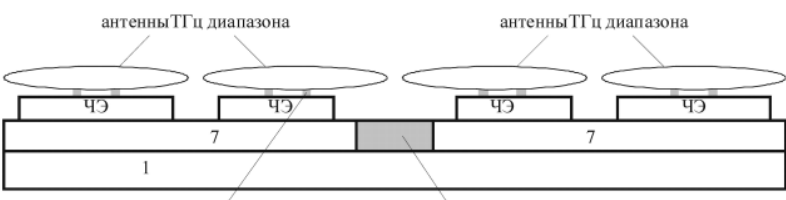

микроконтакт кристаллов смежных субмодулей.

Модернизированы варианты конструкции МФП сверхвысокой размерности, которые устраняют "слепые зоны" (см. рис.). Зазор между кристаллами смежных субмодулей МФП отсутствует или составляет не более 2 мкм. Развитие методологии лазерного разделения пластин в составе технологии прецизионной микросборки кристаллов позволило уменьшить технологические части "слепых зон" МФП до $11 \div 19$ мкм для различных полупроводниковых материалов [1-6].

Применение в МФП дизайнерских принципов, в которых "слепые зоны" виртуально или физически перекрыты смежными ФЧЭ, может обеспечить расстояние между ФЧЭ смежных кристаллов субмодулей $\sim 1 \div 3$ мкм и отсутствие потерь элементов в каждой строке или столбце (см. рис.), т.е. считывания фотосигналов будет происходить без потери информации в каждом кадре изображения, что соответствует достижению предельной $\quad(100 \%$-ой $) \quad$ эффективности преобразования изображений в МФП [1-6].

\section{Литература}

[1] Козлов А.И., Новоселов А.Р. и др. Оптический журнал. 2018. Т.85, №2. С.60-66.

[2] Козлов А.И., Демьяненко М.А. и др. Автометрия. 2016. Т.52, №2. С.115-121.

[3] Новоселов А.Р. Автометрия. 2016. Т.52, №1. С.116-121.

[4] Козлов А.И., Новоселов А.Р. и др. Оптический журнал. 2014. Т.81, №3. С.35-43.

[5] Пат. РФ № 2509391. Новоселов А.Р. Опубл. 10.03.2014. Бюл. №7.

[6] Новоселов А.Р. Автометрия. 2010. Т.46, №6. С.106-115. 